\title{
Fishing nets and video creation: diabetic nephropathy education on screen
}

\author{
Redes de pesca e a criação de vídeo: em tela a educação na nefropatia diabética
}

\author{
Ângela Paveglio Teixeira Farias ${ }^{1}$ (1) $\mid$ angelaptfarias@terra.com.br \\ Morgana Vielmo Cáceres' (D) morgana.caceres@universo.univates.br \\ Manoela Michel Kohl' (D) manoela.kohl@universo.univates.br \\ Márcio Mossmann' (D) marcio.mossmann@univates.br \\ Eduardo Dallazen' (D) eduardo.dallazen@universo.univates.br \\ Isadora Rosy Pontalti1 (1) $\mid$ isadora.pontalti@universo.univates.br
}

\begin{abstract}
Introduction: Noncommunicable Chronic Diseases (NCDs), such as Diabetes and Hypertension are responsible for $2 / 3$ of deaths in the world, with Diabetic Nephropathy (DN) representing the most important cause of chronic kidney disease. Health Literacy (HL) is one of the social determinants of health. To guide and expand the knowledge of patients and teams involved in the care of people with NCDs, and for a better approach to chronic complications of Diabetes and Hypertension, the development of learning objects (LO) was proposed.

Experience Report: this study involved the construction of an educational video by a group of five students during the academic program of undergraduate Medical School in 2019. They proposed a guiding question in relation to DN from a theoretical material. The chosen question was: "What is the level of understanding of patients with diabetic nephropathy in relation to their own disease?". They developed a questionnaire on diabetes and hypertension and their complications, which was answered by patients with diabetes who were treated at the specialized outpatient clinic, aiming to answer the proposed problem. They drew a synthesis from the analysis of the responses, of the possible gaps in relation to the understanding of the diseases. Then, a script was created with the description of these gaps with the medical explanation and an analogy was made with fishing nets for the video production, containing narratives, texts, audios and images. Finally, the video was presented to teachers and students in the classroom.
\end{abstract}

Discussion: The characterization of the video as an LO implies constructing it as an educational component, self-sufficient, reusable and with the possibility of combining it with other LOs as new educational tools.

Conclusion: The educational material was characterized as an LO. It allows pointing out aspects of the progression of DN and recommended medical orientations for the disease. It establishes a tool for group discussions and isolated actions based on succinct and evidence-based medical information. The video validation is undergoing validation for use in health services.

Keywords: Diabetes Complications; Diabetic Nephropathies; Health Literacy; Instructional Film and Video; Problem-Based Learning.

\section{RESUMO}

Introdução: As doenças crônicas não transmissíveis (DCNT), como diabetes e hipertensão, são responsáveis por dois terços das mortes no mundo, sendo a nefropatia diabética (ND) a principal causa de doença renal crônica. O letramento em saúde (LS) constitui um dos determinantes sociais da saúde. Para orientação e ampliação de conhecimento dos pacientes e das equipes envolvidas no cuidado de pessoas com DCNT, e para uma melhor abordagem das complicações crônicas do diabetes e da hipertensão, foi proposta a elaboração de objetos de aprendizagem (OA).

Relato de experiência: O presente trabalho envolveu a construção de um vídeo educacional por um grupo de cinco alunos durante as atividades acadêmicas do curso de Medicina em 2019. Esses alunos propuseram uma questão norteadora em relação à ND a partir de um material teórico. A questão escolhida foi: "Qual é o nível de entendimento dos pacientes com nefropatia diabética em relação à própria doença?". Elaboraram um questionário sobre diabetes e hipertensão e suas complicações, o qual foi respondido por pacientes com diabetes atendidos no ambulatório especializado, buscando atender à problemática proposta. Extraíram uma síntese, a partir da análise das respostas, das possíveis lacunas em relação ao entendimento sobre as doenças. A partir disso, produziram um roteiro e atribuíram uma explicação médica a tais lacunas. O vídeo foi construído com base em uma analogia com redes de pesca e composto por narrativas, textos, áudios e imagens. Ao final, apresentaram o vídeo aos docentes e discentes em sala de aula.

Discussão: Para que se possa caracterizar o vídeo como um $O A$, ele precisa se configurar como componente educacional, autossuficiente, passível de reusabilidade e com possibilidade de combinação com outros $O A$, formando novos objetos educacionais.

Conclusão: O material educativo construído pode ser caracterizado como um OA. Tal material pontua aspectos da evolução da ND, bem como traz orientações médicas preconizadas para a doença, podendo ser usado em discussões em grupo ou em ações isoladas, visto que apresenta informações sucintas e embasadas em literatura. Está em curso o processo de validação do vídeo para uso nos serviços de saúde.

Palavras-chave: Complicações do Diabetes; Nefropatias Diabéticas; Letramento em Saúde; Filme e Vídeo Educativo; Aprendizagem Baseada em Problemas.

1 Universidade do Vale do Taquari, Lajeado, Rio Grande do Sul, Brazil.

Chief Editor: Rosiane Viana Zuza Diniz. $\quad$ ～Associate Editor: Antonio da Silva Menezes Junior.

Received on 06/25/21; Accepted on 09/01/21. | Evaluated by double blind review process. 


\section{INTRODUCTION}

Non-communicable Chronic Diseases (NCDs), such as diabetes and hypertension, are responsible for $2 / 3$ of deaths worldwide. Diabetic nephropathy (DN), or diabetes kidney disease, is a complication that affects $20 \%$ to $40 \%$ of patients with diabetes mellitus (DM) and represents the main cause of chronic kidney disease worldwide ${ }^{1,2}$. DN patients are at increased risk for end-stage renal failure, cardiovascular and infectious diseases and death ${ }^{2,3}$. DN is characterized by persistent microalbuminuria or evident proteinuria, which may be associated with systemic arterial hypertension (SAH) and diabetic retinopathy ${ }^{4,5}$.

The adequate management of chronic diseases comes up against issues such as understanding the disease process. In this sense, the World Health Organization (WHO) identified Health Literacy $(\mathrm{HL})$ as one of the social determinants of health, establishing a relationship between such literacy and the population's quality of life, considering it essential for selfcare $^{6} . \mathrm{HL}$ is the capacity to obtain, process and understand information aiming to make appropriate decisions regarding self-care ${ }^{7}$. It is related to the knowledge of one's own health, better care and cost reduction in health ${ }^{8}$.

To guide and expand the knowledge of patients and teams involved in the care of people with NCDs, the development of learning objects (LO) that address the chronic complications of diabetes and hypertension was proposed.

\section{EXPERIENCE REPORT}

The present study, carried out in 2019 during the academic activities of the undergraduate Medical course, involved the creation of an educational video. Based on the previous reading of theoretical material provided by the teacher, the students, divided into groups of five, had to propose a guiding question related to DN. This report describes the experience developed by the group that defined the following question: "What is the level of understanding of diabetic patients with diabetic nephropathy in relation to the disease itself?". Next, a literature review on DN was carried out, which included epidemiological data, pathophysiological mechanism, diagnosis, treatment and complications. Based on the theoretical framework, a questionnaire was created for patients treated at the Diabetes and Hypertension Outpatient Clinic with a suspected diagnosis of DN, aiming to assess the level of understanding of these patients about the disease. Based on the analysis of the answers, the synthesis of possible gaps in relation to DN knowledge was extracted. A script was then created, in which a medical explanation was given to these gaps. Therefore, the students aimed to develop a material that would contribute to the patient's ability to obtain, process and understand information aiming to make appropriate decisions regarding self-care to attenuate or prevent the chronic complication.

The work is supported by "Vygotsky's ${ }^{9}$ Theory of Learning", according to which there must be social interaction between the individuals, generating new experiences and knowledge. And, for learning to occur, the interaction must take place within the zone of proximal development, which includes two principles: the Actual Development, which constitutes the consolidated knowledge, and the Potential Development, which involves knowledge that the individual will be able to build.

The resulting educational material makes an analogy with the fisherman profession. This profession was chosen because its elements are known and are part of the patients' reality. The fisherman's net represented the renal glomerulus and the fish represented the albumin. The healthy kidney was represented by an intact net, which captures all the fish. The evolution of kidney disease was represented by progressive damage to the net; that is, in the slightly damaged net, a small amount of fish is not captured, representing microalbuminuria, and the heavily damaged net allows the passage of a greater amount of fish, representing macroalbuminuria. In addition to these processes, an infestation of corals in the net simulated glomerulosclerosis.

The video uses an understandable language, without technical terms. It consists of narratives, interacts with the viewer, and includes texts, simple audios and images and animation, explaining since the beginning what DM is, and the pathological mechanism of DN. It should be noted that the symptoms were mentioned, as well as the importance of preventing the complication.

The process of the video creation involved a long research and organization process, being divided into three stages: pre-production, production and post-production. The synopsis was created in the pre-production period. The subject, the analogy and the target audience were defined. The concept of the material was created: explaining diabetic nephropathy using simple language, avoiding technical terms - but if it were necessary to use them, these would be explained based on definitions from reliable databases. The search in the Scientific Electronic Library Online (SciELO), PubMed, Coordenação de Aperfeiçoamento de Pessoal de Nível Superior (Capes), Biblioteca Digital Brasileira de Teses e Dissertações (BTDT), Google Scholar and Red de Revistas Científicas de América Latina y el Caribe, España y Portugal (Redalyc) databases was carried out using the descriptors: Health Education; Health Literacy; Self Care; Kidney Failure, Chronic; and Diabetes Mellitus.

The first scene provides a brief introduction about what $\mathrm{DM}$ is and its prevalence in the world population (0 to $31 \mathrm{~s}$ ). In the second scene, the pathophysiology and evolution of DM 
(32s to $1 \min 15 \mathrm{~s}$ ) was explained. The third scene showed the effects that DM can have on the body/individual, highlighting diabetic nephropathy ( $1 \mathrm{~min} 15 \mathrm{~s}$ to $1 \mathrm{~min} 24 \mathrm{~s})$. Throughout the course of the fourth scene, the explanation about DN continued, and the analogy with the fisherman's profession was introduced ( $1 \mathrm{~min} 25 \mathrm{~s}$ to $1 \mathrm{~min} 36 \mathrm{~s})$. In the fifth scene, the components that are lost with the altered renal function were described, considering that they are eliminated from the body in an analogous manner to the elimination of components by a toilet. It was also explained that toxic substances accumulate in the body when the kidneys do not perform their function correctly. They were represented by the symbol of toxic substances, the skull with crossed bones ( $1 \mathrm{~min} 37 \mathrm{~s}$ to $2 \mathrm{~min} 2 \mathrm{~s}$ ). In the sixth scene, in turn, the concepts of microalbuminuria, macroalbuminuria and renal sclerosis were mentioned, based on illustrations of damage to the fishing net, which represent the damage suffered by the kidney. It also explains glomerular filtration rate and its reduction caused by all these damages (2min3s to 2 min50s). In the seventh scene, the importance of glycemic control and correct DM treatment was reinforced ( $2 \mathrm{~min} 51 \mathrm{~s}$ to $3 \mathrm{~min}$ ). The eighth scene showed the main manifestations and consequences of diabetic nephropathy for the patient: the signs and symptoms caused by the already advanced disease, the progressive loss of renal function, with the consequent need for dialysis treatment or even kidney transplantation ( $3 \min 1 \mathrm{~s}$ to $3 \min 26 \mathrm{~s}$ ). From the ninth scene onwards, aspects of the systemic arterial hypertension contribution were introduced ( $3 \min 27$ to $3 \min 37 \mathrm{~s})$. In the tenth scene, the interference of systemic arterial hypertension was explained, represented by "turbulent" water, which makes renal filtration even more difficult or, according to the analogy with the fisherman's profession, hinders the capture of fish ( $3 \min 38 \mathrm{~s}$ to $4 \mathrm{~min} 1 \mathrm{~s}$ ). In the eleventh scene, measures to be taken by the patients to maintain DM control, prevent severe damage to the kidneys and other organs, and avoid the aforementioned consequences were addressed (4min $2 \mathrm{~s}$ to $4 \min 31 \mathrm{~s})$. In the twelfth scene, there was a positive reinforcement message, to encourage patients to take care of their health ( $4 \mathrm{~min} 32 \mathrm{~s}$ to $4 \mathrm{~min} 44 \mathrm{~s}$ ). The thirteenth and last scene of the video listed the authors, credits, image research bases and references of the entire content that was used to prepare the work ( $4 \mathrm{~min} 45 \mathrm{~s}$ to $5 \mathrm{~min} 30 \mathrm{~s}$ ).

Next, five scenes representing the video are reproduced for illustration purposes (Figures 1, 2, 3, 4 and 5).

The video production phase was carried out in a computer graphics laboratory for video creation and production, at the university's facilities. The lines of the script were recorded by the students who created the content. Afterwards, with the collaboration of a professional with a degree in Advertising and
Figure 1. Fishing net = kidneys.

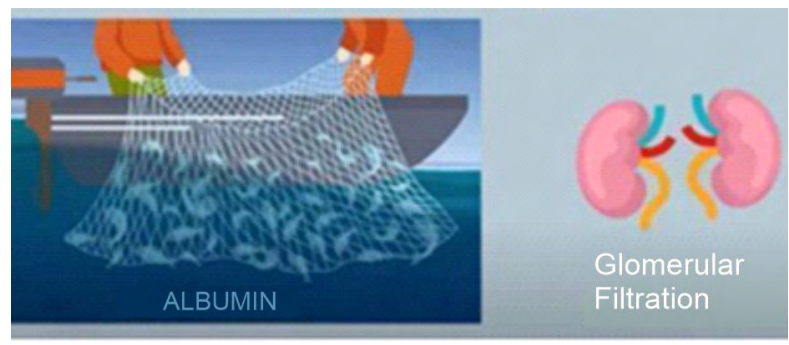

Source: Adapted from Vygotsky's Learning Theory9.

Figure 2. Microalbuminuria.

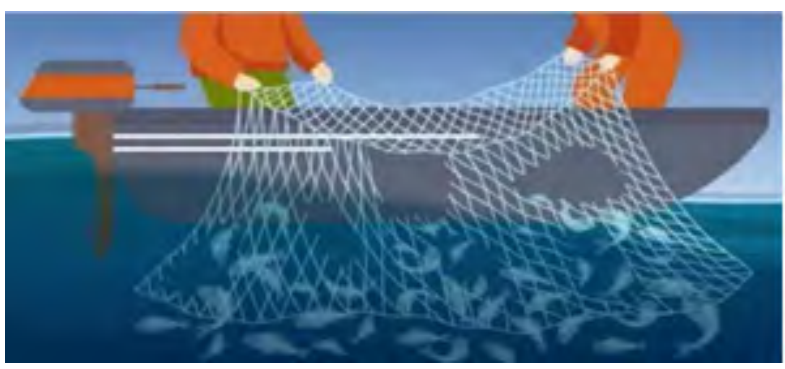

Source: Adapted from Vygotsky's Learning Theory ${ }^{9}$.

Figure 3. Macroalbuminuria.

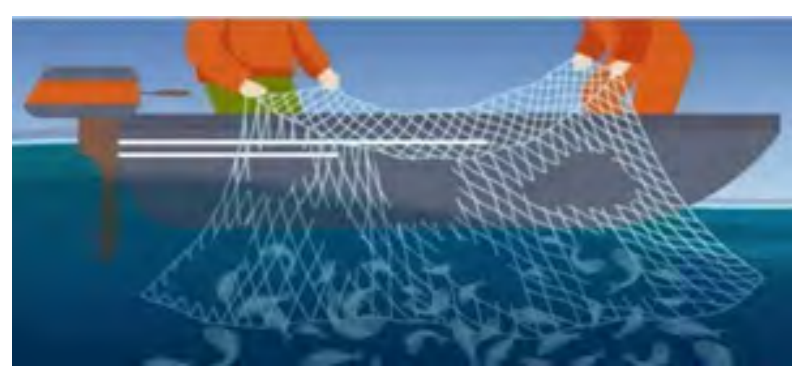

Source: Adapted from Vygotsky's Learning Theory.

Figure 4. Sclerosis.

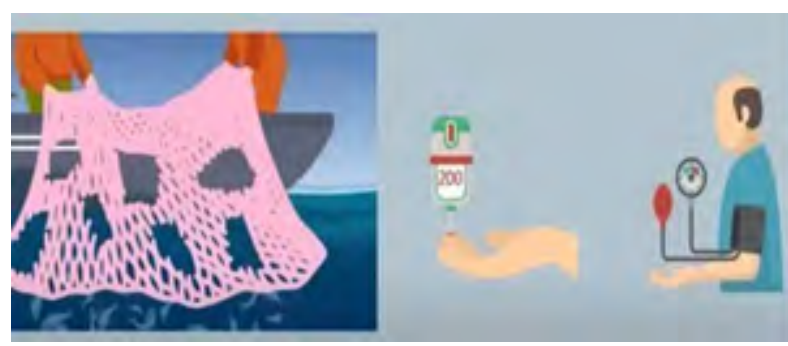

Source: Adapted from Vygotsky's Learning Theory9.

Figure 5. Kidney injury.

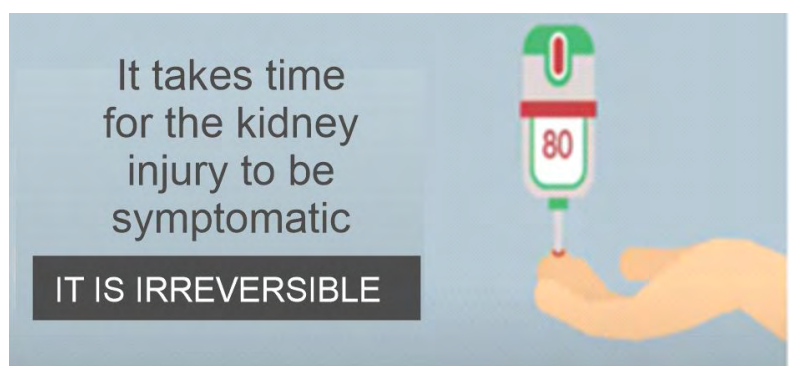

Source: Adapted from Vygotsky's Learning Theory ${ }^{9}$. 
Propaganda, the longest stage began, which was the assembly of the animations with the pre-established vectors. These vectors had to be image-free and had to fit perfectly into the already recorded lines.

The last phase, the post-production one, included editing the images, adding the special effects, introducing background music and the subtitles. This step was carried out by the sector's audiovisual communication technician. After the completion, some modifications were made to improve the video.

The final version of the video has 5 minutes and 30 seconds and consisted of an opening cover, definition of Diabetes Mellitus, its prevalence and the consequences of the poorly controlled disease, including Diabetic Nephropathy and other associated pathologies, such as Systemic Arterial Hypertension. Moreover, risk factors associated with the development of these pathologies were shown, as well as protective factors, which, in a simple way, can be integrated into the habits of our patients and all those who watch the video (available at: https://youtu.be/ faV4mFAvMhE).

After completion, the material was presented to the students of the Diabetes and Hypertension module, to the evaluators and the invited teachers, as well as to the health professionals. It was also presented to a group of ten patients to evaluate the understanding and clarification arising from exposure to the material. The positive feedback motivated the group to present the experience in two congresses, a national congress in the area of Endocrinology and Metabolism and an international congress on Teaching and Learning. A proposal by one of the evaluators to provide the experience of the material to a larger sample of patients came up.

\section{DISCUSSION}

The problem-situation that guided the making of the video made it possible to identify the difficulty that patients have in understanding their disease, as the pathological mechanism is difficult to explain to lay people, and the symptoms of DN only exist in the late evolution. DN starts, on average, about 10 to 15 years after the initial diagnosis in DM1. Regarding DM2, the development of DN does not have a defined onset period, as this disease has a more variable history and late diagnosis. However, DN has a similar clinical course in both ${ }^{5}$.

The content that supported the construction of the video included the pathophysiology of DN. As for the information regarding the diagnosis, the one mentioned in the KDIGO Guideline was chosen, based on the glomerular filtration rate (GFR) and albuminuria levels. These elements are complementary, making the diagnosis more reliable, since some of the diabetic patients have a decrease in GFR, even with normoalbuminuria. This scenario allows the early identification of the pathology and its consequent management ${ }^{4,5}$.

Other relevant steps, presented in sequence in the video content, refer to the correct definition of albuminuria and its pathological evolution. They allow understanding the severity and irreversibility of DN when it progresses to the symptomatic phase. They emphasize the unfavorable prognostic aspect after its onset. In the video conclusion stage, complication prevention practices, lifestyle changes, dietary reeducation actions and physical activity practice were recommended, which are demonstrably favorable to the modification of the late outcome ${ }^{2,10}$.

The educational material was characterized as a learning object because it fits the definition of a small educational component, "self-sufficient"and as a"cell-block". It can be combined with other materials to create new educational objects ${ }^{11,12}$.

The video constitutes an educational component as it aims at providing information, learning and allowing decisionmaking in relation to self-care. It is "self-sufficient" as it does not need additional materials to be understood. Moreover, it is classified as self-contained, that is, it focuses on a subject and explains it without depending on other objects ${ }^{13}$.

The "cell-block" feature is explained by being an integral part of a set of other videos concerning the clarification of chronic complications related to DM and SAH pathologies, which followed the same creation process proposed in the Diabetes and Hypertension module of the undergraduate medical course. They can be used independently or together, depending on the teaching-learning approach of the health-disease process.

Silveira and Carneiro (2012, 2014) $)^{13,14}$ mention other conditions for a given educational resource to be considered a learning object (LO). From this perspective, it is considered that the produced video meets the LO criteria, primarily because it clearly presents a pedagogical objective, namely, proceed with the understanding of the evolution of chronic DN complications. Additionally, there is the prioritizing of the digital medium to facilitate dissemination, and actions can be programmed with the LO, allowing interactivity. The interactivity aspect was not considered at the present time. After the video validation process, the proposal for creating a digital game will be undertaken based on the analogy made with the fisherman profession.

Another point considered is the interaction between users from the LO. The video allows pointing out several aspects of the DN evolution and recommended guidelines. Therefore, it establishes a field for group discussions and actions based on concise information based on the literature. As for the condition of providing user assistance through an accessible interface and instructions, a link and QR code were created 
to be easily scanned through a viable reader on most mobile phones equipped with a camera.

Also, according to Mendes et al. (2004) $)^{15}$ and Tarouco et al. $(2003)^{16}$, the criteria of reusability, adaptability, granularity, accessibility, durability and interoperability must be considered for inclusion in a learning environment. The video meets the criteria of reusability, adaptability, and accessibility, that is, it can be viewed through a link or QR code and can be used multiple times in different teaching and learning environments. Among the abovementioned criteria, granularity was not emphasized, as it is a short video, but the splitting off is feasible. The production includes the durability criterion, but it must be modified in case of an update of diagnostic criteria and guidelines regarding $\mathrm{DN}$.

\section{FINAL CONSIDERATIONS}

The educational material produced was characterized as an LO. This video is part of a joint study aimed at improving the literacy of patients with DM, SAH, complications and associated conditions. It allows the pointing out of aspects of DN evolution and recommended guidelines. It establishes a field for group discussions and actions based on concise information based on the literature.

The need for material validation was perceived at the literature review. Therefore, the LO was submitted to a panel of previously selected judges and to a validated analysis instrument. The validation process is described in another article and is currently being published. After this step, it will be possible to provide access for reusability in educational contexts and request storage in repositories to facilitate its reutilization in several learning environments.

Thinking about improving the $\mathrm{HL}$ and reaching a greater number of patients exposed to the educational material, a larger project was planned, which is currently underway. Exposure to the educational material occurs during patient care. associated with validated instruments in a questionnaire format. It is believed that it can impact perceptions of the health-disease process and have a positive impact on HL.

In this sense, the aim is to provide meaningful learning, intensify the quality of care provided to patients, encourage and integrate health professionals and patients to incorporate prevention and health promotion measures in the DN progression control.

\section{AUTHORS' CONTRIBUTION}

Ângela Paveglio Teixeira Farias: participated in the project design; article design; literature review; writing of the manuscript; transcription of data; data analysis; final review. Márcio Mossmann: participated in the project design and final review. Morgana Vielmo Cáceres, Manoela Michel Kohl, Eduardo Dallazen and Isadora Rosy Pontalti: participated in the article design; literature review; writing of the manuscript; transcription of data; data analysis; final review.

\section{CONFLICTS OF INTEREST}

The authors declare no conflicts of interest.

\section{SOURCES OF FUNDING}

The authors declare no sources of funding.

\section{REFERENCES}

1. International Diabetes Federation. IDF Diabetes Atlas. 8th ed. Brussels, Belgium: International Diabetes Federation; 2017 [access in 12 jan. 2021] Available from: https://diabetesatlas.org/en/.

2. American Diabetes Association. Standards of medical care in diabetes. Diabetes Care. 2019; 42(1):124-38 [access in 6 mar. 2021]. Available from: https://www.diabetes.org.br/profissionais/images/pdf/Diretriz-2019ADA.pdf.

3. Afkarian M, Zelnick LR, Hall YN, Heagerty PJ, Tuttle K, Weiss NS, et al. Clinical manifestations of kidney disease among US adults with diabetes, 19882014. JAMA. 2016 Aug 9; 316(6):602-10. doi: 10.1001/jama.2016.10924.

4. National Kidney Foundation. KDOQI Clinical Practice Guidelines for Diabetes and DRC: 2012 Update. Am J Kidney Dis. 2012;60:850-86.

5. Satirapoj B, Adler SG. Comprehensive approach to diabetic nephropathy. Rim Clinica Res. 2014; 33(3):121-31.

6. Chehuen Neto JA, Costa LA, Estevanin GM, Bignoto TC, Vieira CIR, Pinto $F A R$, et al. Letramento funcional em saúde nos portadores de doenças cardiovasculares crônicas. Ciênc Saúde Colet. 2019;24(3):1121-32. doi: 10.1590/1413-81232018243.02212017.

7. Weiss BD, Mays MZ, Martz W, Castro KM, DeWalt DA, Pignone MP, et al Quick assessment of literacy in primary care: the newest vital sign. Ann Fam Med. 2005;3(6):514-22 [access in 17 jan. 2021]. Available from: http://www.scielo.br/scielo.php?script=sci_arttext\&pid=S1413$81232019000301121 \#$ B3.

8. Antunes ML. A literacia em saúde: investimento na promoção da saúde e na racionalização de custos. In: As bibliotecas da saúde, que futuro? Actas das XI Jornadas APDIS. 2014. p. 123-33 [access in 12 jan. 2021]. Available from: https://repositorio.ipl.pt/handle/10400.21/3582.

9. Vygotsky LS. A formação social da mente: o desenvolvimento social da mente. São Paulo: Martins Fontes; 2007.

10. Sociedade Brasileira de Diabetes. Diretrizes da Sociedade Brasileira de Diabetes (2019-2020). São Paulo: AC Farmacêutica; 2019 [access in 14 jan. 2021]. Available from: https://www.diabetes.org.br/profissionais/images/ DIRETRIZES-COMPLETA-2019-2020.pdf.

11. Wiley DA. Connecting learning objects to instructional design theory: a definition, a metaphor, and a taxonomy. 2000. Available from: https:// www.semanticscholar.org/paper/Connecting-learning-objects-toinstructional-design-Wiley/03fee95ed98d8dc262ccd363a589a235db91e 331\#citing-papers.

12. Rozados HBF. Objetos de aprendizagem no contexto da construção do conhecimento. Ciência \& Desenvolvimento: Revista Eletrônica da Fainor. 2009;2(1):46-63 [access in 12 jan. 2021]. Available from: https:// docplayer.com.br/51009533-Objetos-de-aprendizagem-no-contexto-daconstrucao-do-conhecimento.html.

13. Silveira MS, Carneiro MLF. Diretrizes para a avaliação da usabilidade de objetos de aprendizagem. Anais do Simpósio Brasileiro de Informática na Educação nov. 2012; Rio de Janeiro, Brasil [access in 6 mar. 2021]. Available from: https://professor.ufrgs.br/mara/publications/diretrizespara-avalia\%C3\%A7\%C3\%A3o-da-usabilidade-de-objetos-deaprendizagem. 
14. Carneiro MLF, Silveira MS. Objetos de aprendizagem como elementos facilitadores na educação a distância. Educar em Revista. 2014;(4):23560 [access in 2 mar. 2021]. Available from: http://www.scielo.br/scielo. php?script=sci_arttext\&pid=S0104-40602014000800235\&lng=en\&nrm=iso.

15. Mendes RM, Souza VI, Caregnato SE. A propriedade intelectual na elaboração de objetos de aprendizagem. Anais do $5^{\circ}$ Encontro Nacional de Ciência da Informação; jun 2004; Salvador. Salvador: Ufba; 2004 [access in 17 jan. 2021]. Available from: https://lume.ufrgs.br/handle/10183/548.
16. Tarouco LMR, Fabre MCJM, Tamusiunas FRI. Reusabilidade de objetos educacionais. Revista Novas Tecnologias na Educação. 2003;1(1) [access in 2 mar. 2021]. Available from: https://seer.ufrgs.br/renote/article/ view/13628/7697. 